\title{
PENGARUH BIG FIVE PERSONALITY TRAITS TERHADAP NIAT UNTUK MENGINAP DI GREEN HOTEL DI INDONESIA
}

\author{
Felicia Livia Ganiadi ${ }^{1}$, Bella Jessica Margianto ${ }^{2}$, Monika Kristanti ${ }^{3 *}$ \\ 1,2,3 Program Manajemen Perhotelan, Program Studi Manajemen, Fakultas Bisnis dan Ekonomi, \\ Universitas Kristen Petra, Jl. Siwalankerto 121-131, Surabaya \\ Email: 1iviaganiadi@gmail.com, ${ }^{2}$ belloupss@gmail.com, ${ }^{3}$ mkrist@petra.ac.id \\ *Penulis korespondensi
}

\begin{abstract}
Abstrak
Penelitian ini dilakukan untuk mengetahui pengaruh big five personality traits terhadap niat untuk menginap di green hotel di Indonesia. Big five personality traits merupakan teori yang paling sering digunakan dalam psikologi akademik. Penting untuk mengetahui ciri kepribadian seseorang karena mempengaruhi seseorang untuk memiliki niat untuk menginap yang kemudian mengambil tindakan untuk menginap. Data dikumpulkan dengan menyebarkan kuesioner online kepada 187 masyarakat Indonesia yang berusia 17 tahun keatas dan memahami istilah green hotel dan diolah menggunakan SEM. Hasil menunjukkan bahwa agreeableness dan conscientiousness mempunyai pengaruh yang positif dan signifikan, sedangkan extraversion, neuroticism, dan openness mempunyai pengaruh yang negatif dan tidak signifikan terhadap niat untuk menginap di green hotel, serta agreeableness adalah yang paling dominan terhadap niat untuk menginap di green hotel di Indonesia.
\end{abstract}

Kata kunci: Big five personality traits; Green Hotel; Niat untuk menginap.

\begin{abstract}
The purpose of this research is to understand the influence of big five personality traits towards intention to stay in a green hotel in Indonesia. Big five personality traits is a very common theory used in academic psychology. It is important to know the personality traits of a person because it influences someone to have an intention to stay which then takes action to stay. Data was collected by spreading 187 online questionnaires to Indonesian people over 17 years old and understood the term of green hotel and processed using SEM. The result is agreeableness and conscientiousness have positive and significant influence, while extraversion, neuroticism, and openness have negative and insignificant influence towards intention to stay in green hotel, agreeableness is the most dominant towards intention to stay in green hotel in Indonesia.
\end{abstract}

Keywords: Big five personality traits; Green Hotel; Intention to Stay.

\section{PENDAHULUAN}

Sektor industri perhotelan menghasilkan limbah dan menggunakan energi (listrik, air, dan gas) yang cukup besar sehingga mengakibatkan pencemaran lingkungan. Menurut Kurnia, Syamsinar, dan Afdaliah (2020), hotel menghasilkan limbah padat dan cair. Berdasarkan data dari U.S. Energy Information Administration, fasilitas hotel termasuk dalam peringkat lima keatas yang menggunakan jumlah energi terbesar di bidang komersial (Bohdanowicz, 2006).

Dalam menyikapi masalah pencemaran lingkungan tersebut, beberapa sektor industri hotel dan pariwisata mengimplementasikan program yang ramah lingkungan atau yang biasa disebut dengan "Green Hotel". Menurut Green Hotel Association (2008), green hotel adalah hotel yang menerapkan konsep ramah lingkungan dalam operasionalnya sehingga pada jangka panjang dapat mengurangi dampak negatif terhadap lingkungan. Menurut Mbulu dan Gunadi (2018), program green hotel diterapkan dengan melakukan berbagai kegiatan seperti penghematan energi, penghematan air, memaksimalkan ventilasi udara, dan menggunakan dispenser untuk shampo dan sabun agar dapat diisi ulang. Penghematan energi dilakukan dengan cara menggunakan solar panel, menggunakan kartu kamar untuk menyalakan dan mematikan listrik secara otomatis, dan menggunakan lampu LED yang tahan lama. Penghematan air dilakukan dengan memberikan sensor pada wastafel dan mengolah limbah air untuk menyiram tanaman. Program green hotel telah banyak diterapkan di hotel-hotel di Indonesia, seperti yang dilakukan oleh grup hotel Accor, Hotel "POP!".

Tidak hanya sektor industri hotel, konsumen juga mulai memperhatikan tentang masalah lingkungan. 
Konsumen mulai mencari serta membeli produk dan layanan yang ramah lingkungan (Lee, Hsu, Han \& Kim, 2010). Menurut survei WWF-Indonesia dan Nielsen survey tahun 2017 dalam Dinas Komunikasi dan Informatika Pemerintah Provinsi Jawa Timur (2017), sebanyak 63\% konsumen Indonesia bersedia untuk mengkonsumsi produk ramah lingkungan dengan harga yang lebih tinggi. Kesediaan mengkonsumsi produk ramah lingkungan menunjukkan peningkatan kesadaran konsumen yang mementingkan konsumsi produk ramah lingkungan. Perubahan perilaku konsumen disebabkan oleh kepribadiannya. Menurut Verma, Kumar, dan Chandra (2017), kepribadian berasal dari diri sendiri dan terbentuk sejak pertama kali individu menangkap hal-hal baru yang berasal dari lingkungannya, sedangkan sikap individu terbentuk dari pengalaman proses belajar yang dipengaruhi oleh sekitarnya.

Taryoto (2010) menemukan bahwa ciri-ciri kepribadian orang Indonesia tetap memiliki gengsi yang tinggi dan pendirian yang lemah. Gengsi yang tinggi membuat orang Indonesia ingin mendapatkan pengakuan bahwa orang Indonesia adalah orang yang up-todate dan suka melakukan hal baik sehingga memilih produk dan layanan yang ramah lingkungan. Pendirian yang lemah membuat orang Indonesia mudah terpengaruh oleh lingkungan sekitar untuk peduli dengan lingkungan. Namun, tidak semua orang Indonesia memiliki kepribadian seperti yang dikatakan oleh Taryoto (2010).

Kepribadian adalah keseluruhan cara seorang individu bereaksi dan berinteraksi dengan individu lain (Robbins \& Judge, 2008). Kepribadian mempengaruhi seorang individu dalam mengambil aksi atau berperilaku untuk menentukan keputusan. Menurut Goldberg (1992), terdapat 5 ciri yang selalu muncul pada setiap individu, yaitu agreeableness, extraversion, neuroticism, conscientiousness, dan openness, yang dikenal dengan big five personality traits. Agreeableness adalah perilaku seseorang dalam bersimpati, disenangi oleh orang lain, bersikap hangat, murah hati, dan memiliki hubungan harmonis dengan orang lain (McCrae \& John, 1992). Extraversion merupakan perilaku seseorang yang tegas, aktif, mudah bersosialisasi, dan komunikatif (McCrae \& Costa, 1985). Neuroticism merupakan perilaku dalam memiliki perasaan negatif seperti kemarahan, kecemasan, ketakutan, dan rasa tidak aman tentang apapun (McCrae \& Costa, 1985). Conscientiousness dapat didefinisikan sebagai perilaku di mana individu memiliki kecenderungan untuk menjadi sistematis, disiplin, bertanggung jawab, dan mengikuti prosedur serta norma yang ada (McCrae \& Costa, 1985).
Openness menggambarkan perilaku individu yang memiliki pemikiran terbuka, imajinatif, dan penasaran terhadap pengetahuan serta hal baru yang belum pernah ada sebelumnya (McCrae \& Costa, 1985). Definisi big five personality traits yang dikemukakan oleh McCrae dan Costa (1985), McCrae dan John (1992) masih digunakan hingga sekarang oleh penelitian tentang kepribadian individu seperti penelitian oleh Kvasova (2015) dan Verma et al (2017).

Dari berbagai penelitian terdahulu, jarang sekali ditemukan penelitian tentang big five personality traits dengan perilaku ramah lingkungan, terutama niat untuk menginap di green hotel. Verma et al. (2017) merupakan salah satu dari yang pertama dalam menghubungkan tentang big five personality traits dengan niat untuk menginap di green hotel menemukan bahwa seiring berjalannya waktu dan adanya perkembangan teknologi, hasil penelitian dapat berubah. Selain itu, penemuan dari penelitian Markowitz, Goldberg, Ashton, dan Lee (2012), Milfont dan Sibley (2012), Kvasova (2015) dan Verma et al. (2017) menghasilkan hasil yang berbeda, sehingga membuat pengaruh antara kepribadian dengan kepedulian lingkungan bersifat tidak konsisten dan kontradiktif. Berdasarkan saran penelitian lebih lanjut dari penelitian Verma et al. (2017), diperlukan adanya penelitian lebih dalam tentang big five personality traits dengan niat untuk menginap di green hotel di Indonesia. Menurut Crowe Associates (n.d.), big five personality traits adalah ciri kepribadian yang paling diterima dan paling umum digunakan dalam psikologi akademis. Peneliti menggunakan pengukuran niat kunjungan green hotel yang berasal dari Lee et al. (2010). Penelitian yang dilakukan Lee et al. (2010) merupakan penelitian tentang seberapa jauh image green hotel mempengaruhi niat konsumen dalam pemilihan hotel. Hasil dari penelitian Lee et al. (2010) menunjukkan bahwa image green hotel berpengaruh positif terhadap niat konsumen dalam pemilihan hotel.

\section{TINJAUAN PUSTAKA}

\section{Personality Traits}

Personality traits adalah ciri-ciri dari kepribadian seseorang. Setiap individu memiliki ciri-ciri kepribadian yang berbeda. Ciri-ciri kepribadian dapat didefinisikan sebagai dimensi yang membedakan setiap individu dalam berpikir, mengekspresikan perasaan, serta bertindak dan bereaksi dalam situasi tertentu, seperti seseorang yang memiliki ciri sangat suka berteman biasanya sangat suka berada di sekitar orang (McCrae \& Costa, 2006, p. 25). Ciri-ciri 
kepribadian memiliki lima dimensi besar yang dikenal dengan big five personality traits. Menurut Goldberg (1992), big five personality traits terdiri dari agreeableness, extraversion, neuroticism, conscientiousness, dan openness. Teori ini masih digunakan sebagai acuan dalam berbagai penelitian terkait ciri-ciri kepribadian hingga sekarang.

\section{Dimensi Personality Traits}

Agreeableness adalah ciri kepribadian seseorang yang memiliki simpati, disenangi oleh orang lain, bersikap hangat, murah hati, dan memiliki hubungan harmonis dengan orang lain (McCrae \& John, 1992). Individu dengan agreeableness yang tinggi menunjukkan kemampuan beradaptasi, sedangkan agreeableness yang rendah menunjukkan sifat skeptisisme, menantang ide orang lain dan enggan untuk terlibat masalah (Migliore, 2011). Indikator dari agreeableness adalah:

1. Saya bersimpati kepada perasaan orang lain.

2. Saya peduli dengan masalah orang lain.

3. Saya memahami perasaan orang lain.

4. Saya tertarik untuk berinteraksi dengan orang lain.

Extraversion merupakan ciri kepribadian seseorang yang tegas, aktif, suka bersenang-senang, penuh kasih sayang, mudah bersosialisasi, dan komunikatif (McCrae \& Costa, 1985). Individu dengan extraversion yang rendah menunjukkan ciri introvert, suka bekerja di belakang layar, kurang banyak bicara, pendiam, dan kurang mengarah pada tindakan (Migliore, 2011). Indikator dari extraversion adalah:

1. Saya dapat menghidupkan suasana dalam suatu acara.

2. Saya banyak berbicara.

3. Saya dapat berinteraksi dengan banyak orang dalam suatu acara.

4. Saya lebih suka tampil di depan banyak orang.

Neuroticism merupakan perilaku dalam memiliki perasaan negatif seperti kemarahan, kecemasan, ketakutan, dan rasa tidak aman tentang apa pun (McCrae \& Costa, 1985). Individu dengan neuroticism yang tinggi menunjukkan perilaku yang emosional terhadap perasaan negatif seperti kecemasan, kemarahan atau depresi, sedangkan neuroticism yang rendah menunjukkan ketahanan, ketenangan, dan kemampuan untuk mengendalikan tekanan dan stres (Migliore, 2011). Indikator dari neuroticism adalah:

1. Saya memiliki suasana hati yang mudah berubah.

2. Saya merasa tidak tenang hampir setiap saat.

3. Saya mudah merasa kesal.

4. Saya sering merasa sedih.
Conscientiousness merupakan perilaku di mana individu memiliki kecenderungan untuk menjadi sistematis, disiplin, bertanggung jawab, dan mengikuti prosedur dan norma (McCrae \& Costa, 1985). Individu dengan conscientiousness yang tinggi memiliki perilaku fokus, berhati-hati, dapat diandalkan, dan teratur, sedangkan conscientiousness yang rendah menunjukkan individu yang mudah terganggu, tidak terorganisir, dan tidak memiliki rencana (Migliore, 2011). Indikator dari conscientiousness adalah:

1. Saya segera mengerjakan tugas yang diberikan.

2. Saya selalu ingat mengembalikan barang kembali pada tempatnya.

3. Saya menyukai keteraturan.

4. Saya tidak mengacaukan banyak hal.

Openness menggambarkan perilaku individu yang memiliki pemikiran terbuka, imajinatif, dan penasaran terhadap pengetahuan serta hal baru yang belum pernah ada sebelumnya (McCrae \& Costa, 1985). Individu dengan openness yang tinggi menunjukkan keingintahuan tentang cara berpikir dan perilaku individualistis yang berbeda dengan dirinya, sedangkan nilai yang rendah menunjukkan sikap lebih menyukai hal yang monoton (Migliore, 2011). Indikator dari openness adalah:

1. Saya memiliki imajinasi yang detail.

2. Saya tertarik dengan ide-ide abstrak.

3. Saya mudah memahami ide-ide yang bersifat abstrak.

4. Saya memiliki imajinasi yang baik.

\section{Niat Untuk Menginap}

Niat merupakan awal dari sebuah perilaku yang nampak dan hanya menjadi keinginan berperilaku hingga ada usaha yang dilakukan untuk mengubahnya menjadi sebuah perilaku (Ajzen, 1991). Dalam dunia perhotelan, Han dan Ryu (2007) mendefinisikan niat sebagai keinginan untuk membeli produk dan menggunakan layanan. Niat untuk menginap didefinisikan sebagai kesediaan untuk menginap di suatu tujuan (Chen, Shang, \& Li, 2014). Perilaku individu ditentukan dan dipengaruhi oleh niat individu, beberapa penelitian menunjukkan bahwa niat ditentukan oleh norma yang ada. Niat untuk menginap menurut Lee at al. (2010) meliputi 3 komponen, yaitu:

1. Bersedia untuk menginap di green hotel saat bepergian.

2. Berencana untuk menginap di green hotel saat bepergian.

3. Mengusahakan untuk menginap di green hotel saat bepergian. 
Kerangka Pemikiran

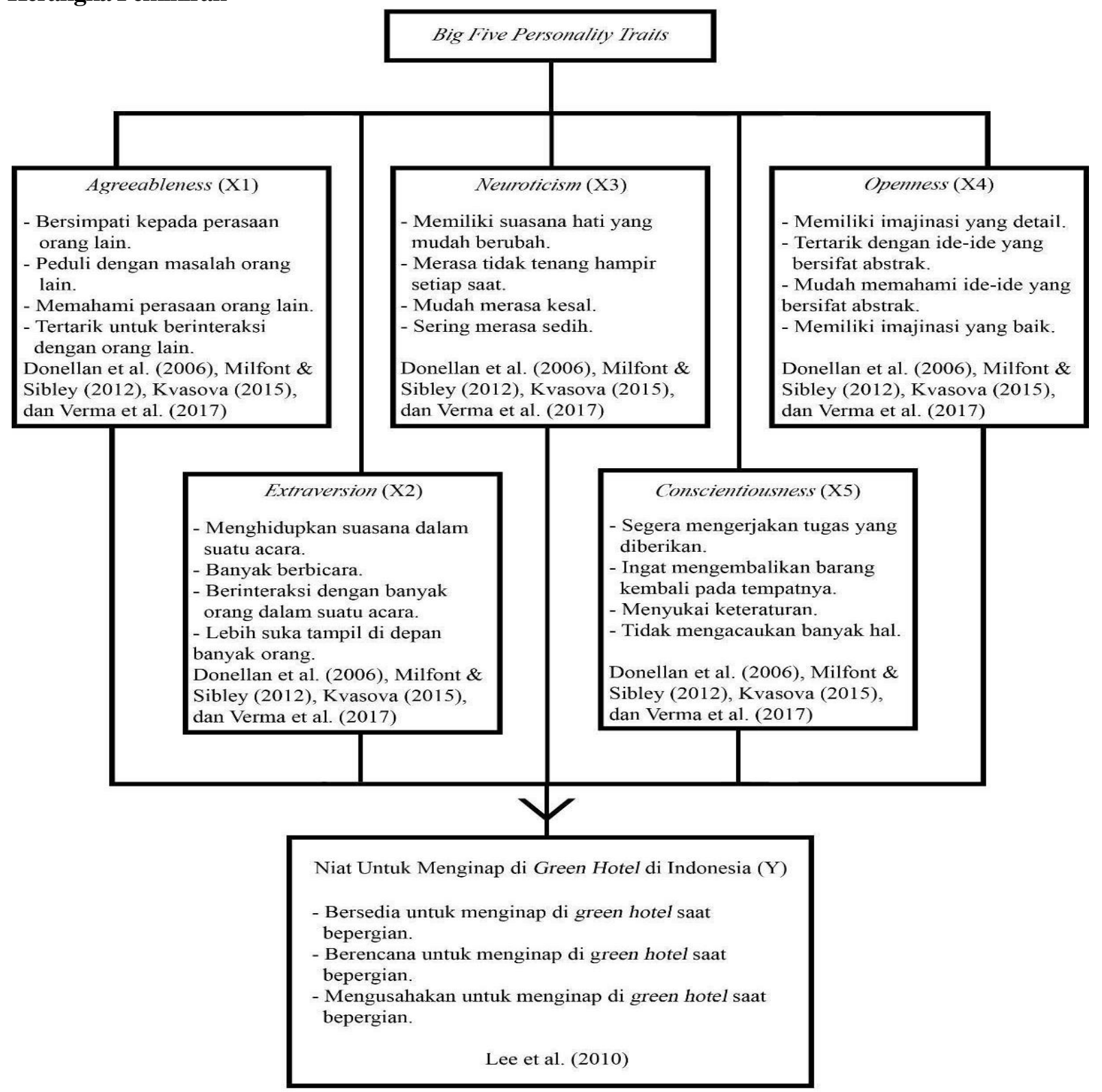

Gambar 1. Kerangka Pemikiran

\section{Hubungan Antar Konsep}

Beberapa penelitian terdahulu yang meneliti tentang lingkungan (Milfont \& Sibley, 2012, dan Verma et al., 2017) menemukan bahwa individu yang memiliki ciri agreeableness yang tinggi cenderung memiliki perilaku ramah lingkungan. Perilaku ramah lingkungan muncul karena individu menganggap bahwa perilaku tersebut memiliki manfaat bagi masyarakat maupun bagi lingkungan hidup. Pengaruh antara agreeableness dengan niat untuk menginap di green hotel telah dilakukan oleh Verma et al. (2017) di India dan menunjukkan bahwa agreeableness memiliki pengaruh yang positif dengan niat untuk menginap di green hotel. Individu yang tidak egois, berempati, dan memiliki belas kasih cenderung lebih ramah lingkungan.

H1: Ciri kepribadian agreeableness berpengaruh positif dan signifikan terhadap niat untuk menginap di green hotel di Indonesia.

Penelitian yang dilakukan oleh Markowitz (2012), dan Verma et al. (2017) tentang kepribadian dan lingkungan menemukan bahwa individu yang memiliki ciri extraversion yang tinggi cenderung menunjukkan perilaku ramah lingkungan yang tinggi. 
Pengaruh antara extraversion dengan niat untuk menginap di green hotel telah dilakukan sebelumnya oleh Verma et al. (2017) melalui penelitiannya di India yang menemukan bahwa ciri extraversion memiliki pengaruh yang positif dengan niat untuk menginap di green hotel.

$\mathrm{H} 2$ : Ciri kepribadian extraversion berpengaruh positif dan signifikan terhadap niat untuk menginap di green hotel di Indonesia.

Penelitian tentang kepribadian dan perilaku ramah lingkungan yang dilakukan oleh Hirsh dan Dolderman (2007) tidak ditemukan pengaruh antara neuroticism dengan perilaku ramah lingkungan. Individu yang memiliki ciri neuroticism yang tinggi lebih khawatir tentang fenomena dengan konsekuensi negatif yang menyebabkan individu mencoba untuk tidak berkontribusi terhadap masalah lingkungan (Hirsh 2010). Pengaruh antara neuroticism dan niat untuk menginap di green hotel yang telah diteliti oleh Verma et al. (2017) di India yang menemukan bahwa neuroticism berpengaruh positif tetapi tidak signifikan terhadap niat untuk menginap di green hotel.

H3: Ciri kepribadian neuroticism berpengaruh positif dan tidak signifikan terhadap niat untuk menginap di green hotel di Indonesia.

Hasil penelitian dari Verma et al. (2017) menemukan bahwa individu yang memiliki ciri conscientiousness sangat berkaitan dengan keterlibatan lingkungan. Individu ini memiliki pemikiran orientasi jangka panjang tentang konsekuensi dari tindakan yang dilakukan dan cenderung merencanakan masa depan yang baik termasuk ekologis (hubungan makhluk hidup dan lingkungannya) yang baik (Milfont \& Sibley, 2012). Pengaruh antara conscientiousness dengan niat untuk menginap di green hotel telah dilakukan oleh Verma et al. (2017) di India, penelitian tersebut menemukan bahwa conscientiousness memiliki pengaruh terhadap niat untuk menginap di green hotel.

H4: Ciri kepribadian conscientiousness berpengaruh positif dan signifikan terhadap niat untuk menginap di green hotel di Indonesia.

Individu yang memiliki ciri openness sangat berkaitan dengan penghargaan dan pengetahuan secara intelektual yang merangsang niat seseorang untuk melindungi lingkungan (Hirsh \& Dolderman 2007; Markowitz et al., 2012, dan Verma et al., 2017). Pengaruh antara openness dengan niat untuk menginap di green hotel telah dilakukan sebelumnya oleh Verma et al. (2017) melalui penelitiannya di India yang menemukan bahwa openness memiliki pengaruh terhadap niat untuk menginap di green hotel.

H5: Ciri kepribadian openness berpengaruh positif dan signifikan terhadap niat untuk menginap di green hotel di Indonesia.

Menurut Taryoto (2010), Mochtar Lubis tahun 1977 menyebutkan bahwa, ciri-ciri orang Indonesia memiliki gengsi yang tinggi dan pendirian yang lemah. 30 tahun kemudian, Taryoto (2010) menelaah ulang apakah benar ciri-ciri kepribadian orang Indonesia adalah seperti itu. Taryoto (2010) menemukan bahwa ciri kepribadian orang Indonesia ini mengarah kepada ciri kepribadian agreeableness yang mudah mengalah sehingga terbawa arus untuk mengikuti trend yang ada di lingkungannya.

H6: Ciri kepribadian agreeableness memiliki pengaruh paling dominan terhadap niat untuk menginap di green hotel di Indonesia.

\section{METODE PENELITIAN}

Metode kuantitatif kausal adalah metode penelitian yang digunakan untuk penelitian ini (Sugiyono, 2015). Populasi dalam penelitian ini adalah masyarakat Indonesia. Teknik sampling yang dipergunakan dalam penelitian ini adalah non-probability sampling dengan jenis purposive sampling yaitu teknik pengambilan sampel dengan kriteria yang ditentukan oleh peneliti (Sugiyono, 2015). Sampel yang ditetapkan oleh peneliti dalam penelitian ini adalah responden yang memahami tentang istilah green hotel yang diukur melalui pertanyaan tentang green hotel dan responden yang berusia minimal 17 tahun, dengan asumsi sudah dewasa menurut usia dan dapat memberikan penilaian terhadap persepsinya mengenai green hotel di Indonesia. Jumlah sampel dalam penelitian ini adalah sebanyak 187 responden sesuai dengan kriteria yang ditentukan oleh peneliti yang dikumpulkan dengan cara membagikan kuesioner online berupa google form secara pribadi kepada keluarga dan teman. Jenis data yang digunakan dalam penelitian ini adalah kuantitatif dengan menyebarkan kuesioner sehingga jenis data yang diperoleh merupakan data kuantitatif atau yang dikenal sebagai data numerik (Sugiyono, 2015).

Teknik analisa data yang digunakan dalam penelitian ini adalah analisis deskriptif serta Structural Equation Modeling (SEM) dengan menggunakan aplikasi Analysis Moment of Structure (AMOS) versi 26. Adapun analisis deskriptif yang digunakan adalah mean dan standar deviasi. 


\section{HASIL PENELITIAN DAN PEMBAHASAN}

\section{Loading Factor}

Nilai loading factor untuk dapat menyatakan bahwa indikator valid dalam menjelaskan variabelnya adalah $\geq 0,6$ tetapi jika nilai loading factor $\geq 0,4$ indikator masih dapat diterima.

Nilai loading factor seluruhnya lebih tinggi dari nilai cut off value sehingga dapat disimpulkan bahwa seluruh indikator dinyatakan valid dalam mengukur variabelnya.

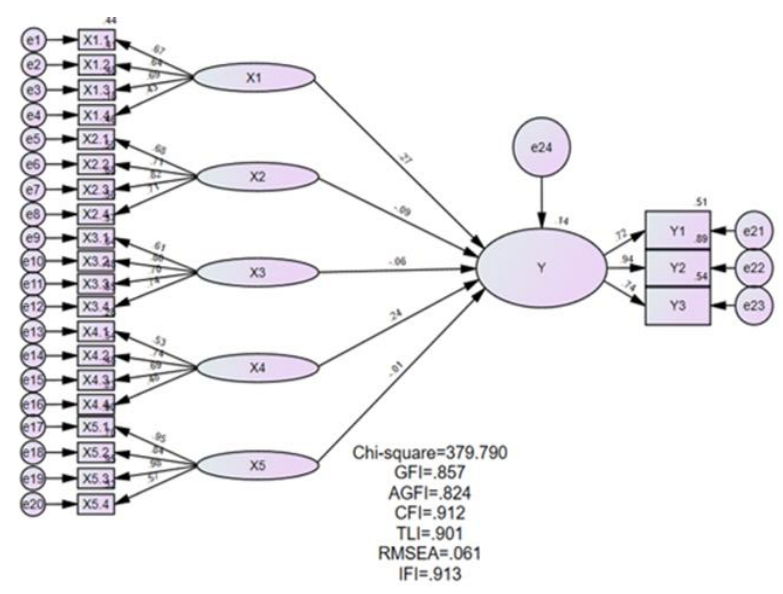

Gambar 2. Model SEM

\section{Composite Reliability}

Nilai composite reliability untuk menyatakan indikator reliabel dalam menjelaskan variabelnya adalah $\geq 0,7$.

Tabel 1. Composite reliability

\begin{tabular}{cc}
\hline Variabel & Composite Reliability (c.r.) \\
\hline Agreeableness & 0,703 \\
Extraversion & 0,821 \\
Neuroticism & 0,806 \\
Conscientiousness & 0,706 \\
Openness & 0,907 \\
Niat untuk Menginap & 0,844 \\
\hline
\end{tabular}

Nilai composite reliability dari setiap variabel lebih besar dari 0,7 sehingga setiap indikator dari masing-masing variabel dapat dikatakan reliabel dalam mengukur variabel latennya.
Average Variance Extracted (AVE) dan Akar AVE

Tabel 2. AVE dan Akar AVE

\begin{tabular}{lccc}
\hline \multicolumn{1}{c}{ Variabel } & AVE & Akar AVE & $\begin{array}{c}\text { Korelasi } \\
\text { Variabel }\end{array}$ \\
\hline Agreeableness & 0,379 & 0,615 & 0,267 \\
Extraversion & 0,536 & 0,732 & $-0,090$ \\
Neuroticism & 0,511 & 0,715 & $-0,059$ \\
Conscientiousness & 0,383 & 0,619 & 0,239 \\
Openness & 0,716 & 0,646 & $-0,009$ \\
Niat untuk & 0,649 & 0,805 & - \\
Menginap & & & \\
\hline
\end{tabular}

Nilai $A V E$ tidak semuanya melebihi 0,5 . Menurut Haryono (2016), syarat convergent validity terpenuhi jika nilai loading factor dan composite reliability untuk semua indikator sudah valid dan reliabel. Jadi, walaupun nilai $A V E$ tidak semua melebihi 0,5 , convergent validity tetap terpenuhi.

\section{Discriminant Validity}

Nilai akar $A V E$ setiap variabel lebih tinggi daripada nilai korelasi variabel sehingga hasil penelitian dikatakan telah memenuhi syarat discriminant validity. Nilai korelasi variabel yang dimiliki oleh agreeableness dan conscientiousness terhadap niat untuk menginap menunjukkan nilai yang positif. Hal ini berarti bahwa agreeableness dan conscientiousness memiliki hubungan yang positif terhadap niat untuk menginap. Sedangkan nilai korelasi variabel yang dimiliki oleh extraversion, neuroticism, dan openness terhadap niat untuk menginap menunjukkan nilai yang negatif. Hal ini berarti bahwa extraversion, neuroticism, dan openness memiliki hubungan yang negatif terhadap niat untuk menginap.

\section{Uji Hipotesis}

\section{a. T Statistik}

T Statistik dilakukan untuk melihat hipotesis dapat diterima serta signifikan atau sebaliknya dengan membandingkan nilai thitung dengan nilai kritisnya. $\mathrm{T}$ hitung dalam SEM adalah CR (Critical Ratio). Hipotesis diterima atau signifikan jika nilai $\mathrm{CR} \geq 1,96$ atau nilai $\mathrm{p} \leq 0,05$. 
Tabel 4. T Statistik

\begin{tabular}{cccccc}
\hline Variabel & $\begin{array}{c}\text { Std. } \\
\text { Estimate }\end{array}$ & SE & CR & P & Ket \\
\hline $\begin{array}{c}\text { Agreeableness } \rightarrow \\
\text { niat menginap }\end{array}$ & 0,35 & 0,13 & 2,63 & 0,01 & Terima \\
$\begin{array}{c}\text { Extraversion } \rightarrow \text { niat } \\
\text { menginap }\end{array}$ & $-0,05$ & 0,05 & $-1,12$ & 0,26 & Tolak \\
$\begin{array}{c}\text { Neuroticism } \rightarrow \text { niat } \\
\text { menginap }\end{array}$ & $-0,04$ & 0,05 & $-0,73$ & 0,47 & Tolak \\
$\begin{array}{c}\text { Conscientiousness } \\
\rightarrow \text { niat menginap }\end{array}$ & 0,31 & 0,12 & 2,51 & 0,01 & Terima \\
$\begin{array}{c}\text { Openness } \rightarrow \text { niat } \\
\text { menginap }\end{array}$ & $-0,01$ & 0,08 & $-0,12$ & 0,90 & Tolak \\
\hline
\end{tabular}

Hasil uji T Statistik menerima hipotesis H1 yaitu "ciri kepribadian agreeableness berpengaruh positif dan signifikan terhadap niat untuk menginap di green hotel di Indonesia" dan H4 yaitu "ciri kepribadian conscientiousness berpengaruh positif dan signifikan terhadap niat untuk menginap di green hotel di Indonesia". Sedangkan hipotesis H2 yaitu "ciri kepribadian extraversion berpengaruh positif dan signifikan terhadap niat untuk menginap di green hotel di Indonesia", H3 yaitu "ciri kepribadian neuroticism berpengaruh positif dan tidak signifikan terhadap niat untuk menginap di green hotel di Indonesia", dan H5 yaitu "ciri kepribadian openness berpengaruh positif dan signifikan terhadap niat untuk menginap di green hotel di Indonesia" ditolak.

\section{b. Squared Multiple Correlation (R-Square atau $\left.\mathbf{R}^{2}\right)$}

$R$-Square digunakan untuk melihat besar persentase variabel independen menjelaskan variabel dependennya.

Tabel 5. R Square

\begin{tabular}{cc}
\hline Variabel & R-Square \\
\hline Big Five Personality Traits & 0,111 \\
\hline
\end{tabular}

Nilai $R$-Square untuk big five personality traits adalah 0,111 yang berarti niat untuk menginap di green hotel dipengaruhi oleh big five personality traits sebesar $11,1 \%$ dan $88,9 \%$ dijelaskan oleh faktor lain diluar faktor yang diteliti oleh peneliti.

\section{c. Q-Square Predictive Relevance $\left(\mathbf{Q}^{2}\right)$}

Selain melakukan uji $R$-Square juga dilakukan uji $\mathrm{Q}^{2}$ untuk melihat predictive relevance dari model.

$$
\begin{aligned}
\mathrm{Q}^{2} & =1-(1-0,111) \\
& =1-(0,889) \\
& =0,111
\end{aligned}
$$

Hasil dari $\mathrm{Q}^{2}$ sebesar 0,111 berarti bahwa niat untuk menginap dipengaruhi oleh ciri kepribadian (big five personality traits) sebesar $11,1 \%$.

\section{Pembahasan}

Mayoritas responden yang pernah menginap di green hotel di Indonesia adalah perempuan berusia 1726 tahun dengan pendidikan terakhir S1 dan berprofesi sebagai pegawai swasta, memiliki pendapatan atau uang saku per bulan Rp 2.500.000,00 - Rp 5.000.000,00. Peneliti menyebarkan kuesioner secara online kepada kerabat dan keluarga melalui personal approach dengan cara mengirim pesan secara personal sehingga peneliti dapat memastikan bahwa responden paham arti green hotel dan contoh hotel yang menerapkan green hotel.

Hasil penelitian ini membuktikan bahwa hipotesis pertama yaitu ciri kepribadian agreeableness terbukti memiliki pengaruh yang positif dan signifikan terhadap niat untuk menginap di green hotel di Indonesia. Agreeableness juga terbukti sebagai ciri kepribadian yang memiliki pengaruh paling dominan terhadap niat untuk menginap di green hotel di Indonesia. Indikator yang paling menjelaskan ciri kepribadian agreeableness adalah "saya memahami perasaan orang lain". Mean dari jawaban responden menunjukkan bahwa mayoritas orang Indonesia merupakan individu yang bersimpati kepada perasaan orang lain dan seringkali sangat mempertimbangkan apa yang dirasakan oleh orang lain sehingga ketika orang lain menyampaikan kekhawatirannya terhadap lingkungan, individu dengan ciri kepribadian agreeableness yang tinggi cenderung untuk ikut peduli terhadap lingkungan. Hal ini sejalan dengan penelitian Milfont dan Sibley (2012) dan Kvasova (2015) tentang individu dengan ciri kepribadian agreeableness yang memiliki perilaku peduli terhadap lingkungan. Selain itu, hal ini juga didukung oleh penelitian Verma et al. (2017) yang menemukan bahwa individu dengan ciri kepribadian agreeableness memiliki niat untuk berkunjung ke green hotel. Dapat disimpulkan bahwa individu dengan ciri kepribadian agreeableness memiliki niat untuk menginap di green hotel di Indonesia. Ciri kepribadian agreeableness merupakan ciri kepribadian yang memiliki pengaruh paling dominan terhadap niat untuk menginap di green hotel di Indonesia, sehingga H6 diterima. Hal ini sesuai dengan Taryoto (2010) yang mengatakan bahwa orang Indonesia memiliki gengsi yang tinggi dan pendirian yang lemah. Gengsi yang tinggi membuat orang Indonesia ingin mendapatkan pengakuan sebagai orang yang up-to-date dan suka melakukan hal baik 
dengan memilih produk dan layanan yang ramah lingkungan. Pendirian yang lemah membuat orang Indonesia mudah terpengaruh oleh lingkungan sekitar untuk peduli dengan lingkungannya. Ciri kepribadian tersebut mengarah kepada ciri kepribadian agreeableness yang menyukai keharmonisan dan mudah mengalah sehingga terbawa arus untuk mengikuti tren peduli lingkungan.

Hasil penelitian ini membuktikan bahwa ciri kepribadian extraversion tidak terbukti memiliki pengaruh yang positif dan signifikan terhadap niat untuk menginap di green hotel di Indonesia. Ciri kepribadian extraversion berpengaruh negatif dan tidak signifikan terhadap niat untuk menginap di green hotel di Indonesia. Hal ini berarti bahwa semakin rendah tingkat seorang individu memiliki ciri kepribadian extraversion, maka semakin tinggi niat untuk menginap di green hotel di Indonesia. Sehingga hipotesis kedua tidak dapat diterima. Indikator yang paling menjelaskan ciri kepribadian extraversion adalah "saya dapat berinteraksi dengan banyak orang dalam suatu acara". Hal ini sesuai dengan penelitian dari Hirsh (2010) dan Hirsh dan Dodlerman (2007) yang menemukan bahwa extraversion memiliki pengaruh negatif dan tidak signifikan terhadap perilaku peduli lingkungan. Dapat disimpulkan bahwa individu dengan ciri kepribadian extraversion tidak memiliki niat untuk menginap di green hotel. Mean dari jawaban responden menunjukkan bahwa mayoritas orang Indonesia merupakan individu yang dapat melakukan interaksi dengan banyak orang dalam suatu acara. Individu dengan kepribadian extraversion suka hal yang menyenangkan bagi dirinya dan tidak membuat dirinya susah sehingga cenderung tidak memiliki niat untuk menginap ke green hotel karena banyaknya aturan atau batasan yang diterapkan oleh program green hotel membuat dirinya kurang senang.

Hasil penelitian ini membuktikan bahwa ciri kepribadian neuroticism tidak terbukti memiliki pengaruh yang positif dan tidak signifikan terhadap niat untuk menginap di green hotel di Indonesia. Ciri kepribadian neuroticism berpengaruh negatif dan tidak signifikan terhadap niat untuk menginap di green hotel di Indonesia. Hal ini merupakan sesuatu yang baik karena semakin rendah tingkat seorang individu memiliki ciri kepribadian neuroticism yaitu perasaan negatif, maka semakin tinggi niat untuk menginap di green hotel di Indonesia. Sehingga hipotesis ketiga tidak dapat diterima. Indikator yang paling menjelaskan ciri kepribadian neuroticism adalah "saya merasa tidak tenang hampir setiap saat". Mean dari jawaban responden menunjukkan bahwa orang Indonesia merupakan individu yang memiliki suasana hati yang mudah berubah. Seorang individu yang mudah berubah suasana hatinya seringkali tidak konsisten terhadap pilihannya sehingga munculnya niat untuk menginap di green hotel tergantung dari suasana hatinya. Hal ini sejalan dengan penelitian Markowitz et al. (2012) dan Milfont dan Sibley (2012) tentang individu dengan ciri kepribadian neuroticism memiliki pengaruh negatif dan tidak signifikan terhadap perilaku peduli lingkungan. Dapat disimpulkan bahwa individu dengan ciri kepribadian neuroticism tidak memiliki niat untuk menginap di green hotel.

Hasil penelitian ini membuktikan bahwa hipotesis keempat yaitu ciri kepribadian conscientiousness terbukti memiliki pengaruh yang positif dan signifikan terhadap niat untuk menginap di green hotel di Indonesia. Indikator yang paling menjelaskan ciri kepribadian conscientiousness adalah "saya selalu ingat mengembalikan barang kembali pada tempatnya". Mean dari jawaban responden menunjukkan bahwa orang Indonesia merupakan individu yang menyukai keteraturan. Individu ini taat terhadap aturan atau norma yang berlaku sehingga sangat peduli terhadap lingkungan. Hal ini sejalan dengan penelitian Markowitz et al. (2012), Milfont dan Sibley (2012), dan Kvasova (2015) tentang individu dengan ciri kepribadian conscientiousness yang memiliki perilaku peduli terhadap lingkungan. Selain itu, hal ini juga didukung oleh penelitian Verma et al. (2017) yang menemukan bahwa individu dengan ciri kepribadian conscientiousness memiliki niat untuk berkunjung ke green hotel. Dapat disimpulkan bahwa individu dengan ciri kepribadian conscientiousness memiliki niat untuk menginap di green hotel di Indonesia.

Hasil penelitian ini membuktikan bahwa ciri kepribadian openness tidak terbukti memiliki pengaruh yang positif dan signifikan terhadap niat untuk menginap di green hotel di Indonesia. Ciri kepribadian openness berpengaruh negatif dan tidak signifikan terhadap niat untuk menginap di green hotel di Indonesia. Hal ini berarti bahwa semakin rendah tingkat seorang individu memiliki ciri kepribadian openness, maka semakin tinggi niat untuk menginap di green hotel di Indonesia. Sehingga hipotesis kelima tidak dapat diterima. Indikator yang paling menjelaskan ciri kepribadian openness adalah "saya mudah memahami ide-ide yang bersifat abstrak". Mean dari jawaban responden menunjukkan bahwa orang Indonesia merupakan individu yang memiliki imajinasi yang baik. Seorang individu dengan imajinasi yang baik memiliki pemikiran yang terbuka dan tertarik untuk mencoba hal-hal baru meskipun kegiatan tersebut dapat merusak lingkungan. Hal ini sejalan dengan hasil dari penelitian Kvasova (2015) yang 
menemukan bahwa openness memiliki pengaruh negatif dan tidak signifikan terhadap perilaku peduli lingkungan. Dapat disimpulkan bahwa individu dengan ciri kepribadian openness tidak memiliki niat untuk menginap di green hotel.

\section{SIMPULAN DAN SARAN}

\section{Kesimpulan}

Ciri kepribadian agreeableness memiliki hubungan yang positif dan signifikan terhadap niat untuk menginap di green hotel di Indonesia dan indikator yang paling menjelaskan adalah "saya memahami perasaan orang lain". Ciri kepribadian extraversion memiliki hubungan yang negatif dan tidak signifikan terhadap niat untuk menginap di green hotel di Indonesia dan indikator yang paling menjelaskan adalah "saya dapat berinteraksi dengan banyak orang dalam suatu acara". Ciri kepribadian neuroticism memiliki hubungan yang negatif dan tidak signifikan terhadap niat untuk menginap di green hotel di Indonesia dan Indikator yang paling menjelaskan adalah "saya merasa tidak tenang hampir setiap saat". Ciri kepribadian conscientiousness memiliki hubungan yang positif dan signifikan terhadap niat untuk menginap di green hotel di Indonesia dan indikator yang paling menjelaskan adalah "saya selalu ingat mengembalikan barang kembali pada tempatnya". Ciri kepribadian openness memiliki hubungan yang negatif dan tidak signifikan terhadap niat untuk menginap di green hotel di Indonesia dan indikator yang paling menjelaskan adalah "saya mudah memahami ide-ide yang bersifat abstrak". Ciri kepribadian yang memiliki pengaruh paling dominan terhadap niat untuk menginap di green hotel di Indonesia adalah agreeableness.

\section{Saran}

Hasil penelitian ini menunjukkan bahwa konsumen Indonesia secara umum memiliki ciri kepribadian agreeableness yaitu orang yang memiliki pendirian yang lemah dan mudah dipengaruhi oleh orang-orang di sekitarnya sehingga niat untuk menginap dapat dibentuk dengan cara mengubah pendirian konsumen Indonesia yang awalnya tidak berniat untuk menginap menjadi berniat untuk menginap. Pihak manajemen hotel dapat memikirkan hal-hal yang dapat merubah pendirian orang Indonesia menjadi peduli lingkungan dan berniat untuk menginap ke green hotel dengan cara mengedukasi konsumen menggunakan poster-poster yang mengajak konsumen untuk lebih peduli lingkungan dan melakukan promosi yang menunjukkan bahwa konsumen perlu menginap di hotel yang menerapkan program green hotel.

Responden dari penelitian ini sebagian besar merupakan penduduk Surabaya. Penduduk Surabaya bisa jadi memiliki ciri kepribadian yang berbeda dengan penduduk yang berada di daerah lain di Indonesia. Peneliti selanjutnya dapat menyebarkan kuesioner kepada penduduk yang berada di seluruh daerah di Indonesia. Hasil dari penelitian ini dapat berubah seiring berjalannya waktu karena ciri kepribadian orang Indonesia dapat berubah mengikuti tren yang ada sehingga perlu untuk dilakukan penelitian ulang beberapa tahun kedepan.

\section{DAFTAR REFERENSI}

Ajzen, I. (1991). The theory of planned behavior. Organizational Behavior and Human Decision Processes, 50(2), 179-211.

Bohdanowicz, P. (2006). Responsible resource management in hotels: Attitudes, indicators, tools and strategies. (Doctoral thesis). KTH Industrial Engineering and Management, Stockholm, Sweden.

Chen, Y. C., Shang, R. A., \& Li, M. J. (2014). The effects of perceived relevance of travel blogs' content on the behavioral intention to visit a tourist destination. Computers in Human Behavior, 30, 787-799.

Crowe Associates. (n.d.). The "big 5" personality traits. Retrieved from http://www.crowe-associates.co.uk/coaching-tools/the-big-5-personality-traits/

Dinas Komunikasi dan Informatika Pemerintah Provinsi Jawa Timur. (2017). Kesadaran konsumen konsumsi produk ramah lingkungan meningkat. Retrieved from http://kominfo.jatimprov.go.id/ $\mathrm{read} / \mathrm{umum} /$ kesadaran-konsumen-konsumsiproduk-ramah-lingkungan-meningkat

Donnellan, M. B., Oswald, F. L., Baird, B. M., \& Lucas, R. E. (2006). The miniIPIP scales: Tiny yet effective measures of the big five factors of personality. Psychological assessment, 18(2), 192.

Green Hotel Association. (2008). What are green hotels?. Retrieved from http://greenhotels.com/ index.php

Goldberg, L. R. (1992). The development of markers for the big-five factor structure. Psychological Assessment, 4(1), 26-42. 
Han, H., \& Ryu, K. (2007). Moderating role of personal characteristics in forming restaurant customers' behavioral intentions: An upscale restaurant setting. Journal of Hospitality \& Leisure Marketing, 15(4), 25-54.

Haryono, S. (2016). Metode SEM untuk penelitian manajemen AMOS LISREL PLS. Bekasi, Indonesia: Intermedia Personalia Utama.

Hirsh J. B., 2010. Personality and environmental concern. Journal of Environmental Psychology, 30, 245-248.

Hirsh J. B. and Dolderman D., 2007. Personality predictors of consumerism and environmentalism: A preliminary study. Personality and Individual Differences, 43, 1583-1593.

Kurnia, S., Syamsinar, \& Afdaliah. (2020). Akuntansi manajemen limbah industri perhotelan (Studi kasus: Sebuah hotel bintang empat di Makassar). Akunsika: Jurnal Akuntansi dan Keuangan, 1(1).

Kvasova, O. (2015). The big five personality traits as antecedents of eco-friendly tourist behavior. Personality and Individual Differences, 83, 111116.

Lee, J. S., Hsu, L. T., Han, H., \& Kim, Y. (2010). Understanding how consumers view green hotels: How a hotel's green image can influence behavioural intentions. Journal of sustainable tourism, 18(7), 901-914.

Markowitz, E. M., Goldberg, L. R., Ashton, M. C., \& Lee, K. (2012). Profiling the "pro-environmental individual": A personality perspective. Journal of personality, 80(1), 81-111.

Mbulu, Y. P., \& Gunadi, I. M. A. (2018). Green hotel and its implementation in Indonesia (Case study: Aston Hotel \& Resort Bogor, Neo Hotel, and
Fave Hotel). Advances in Economics, Business and Management Research (AEBMR), 52, 312322.

McCrae, R. R., \& Costa Jr, P. T. (1985). Comparison of EPI and psychoticism scales with measures of the five-factor model of personality. Personality and individual Differences, 6(5), 587-597.

McCrae, R. R., \& Costa, P. T. (2006). Personality in adulthood: A five-factor theory perspective. New York, United States of America.

McCrae, R. R., \& John, O. P. (1992). An introduction to the five-factor model and its applications. Journal of personality, 60(2), 175-215.

Migliore, L. A. (2011). Relation between big five personality traits and hofstede's cultural dimensions. Cross Cultural Management: An International Journal, 18(1), 40.

Milfont, T. L., \& Sibley, C. G. (2012). The big five personality traits and environmental engagement: Associations at the individual and societal Level. Journal of Environmental Psychology, 32(2), 187-195.

Robbins, S. P \& Judge, T. A. (2008). Perilaku organisasi buku 1. Jakarta: Salemba Empat.

Sugiyono, B. (2015). Metode penelitian pendidikan pendekatan kualitatif, kuantitatif, dan $R \& D$. Bandung: CV Alfabeta.

Taryoto, A. H. (2010). Telaahan ulang ciri-ciri manusia Indonesia. Bogor: Sekolah Tinggi Perikanan.

Verma, V. K., Kumar, S., \& Chandra, B. (2017). Big five personality traits and tourist's intention to visit green hotels. Indian Journal of Scientific Research, 15(2), 79-8. 